\title{
塑性理論による鉄筋コンクリート部材の面内せん断耐力評価 \\ ULTIMATE STRENGTH OF REINFORCED CONCRETE MEMBERS SUBJECTED TO IN-PLANE SHEAR STRESSES ESTIMATED BY PLASTIC THEORY
}

\author{
吉川弘道* ・田辺忠顕** \\ By Hiromichi YOSHIKAWA and Tada-aki TANABE
}

\begin{abstract}
The plastic theory by M.P. Nielsen was adopted to predict the ultimate strength of a reinforced concrete member subjected to in-plane stresses. Furthermore, the authors develop the plastic theory by describing it in terms of nondimensional quantities and by introducing the effectiveness factor of cracked concrete. Values calculated by the theory are in reasonably good agreement with experimental results obtained from torsional loading tests. However, further studies, including estimating the shear strength of over-reinforced concrete members and values of the effectiveness factor of concrete, are required.
\end{abstract}

Keywords: plastic theory, in-plane shear, reinforced concrete panel, effectiveness factor, degree of reinforcement, failure modes, nondimensional description

\section{1. まえがき}

原子力発電所におけるコンクリート製格納容器 (CCV) の採用, およびコンクリート製地下式 LNG 貯槽の建設を契機として, 鉄筋コンクリート部材の面内 せん断に関する研究が盛んとなった。なかんづく, 面内 せん断耐力の合理的な評価手法が過去 10 数年間の主要 な議論の 1 つであった. その結果，実験的手法によるも $の^{1), 2)}$, 解析的手法によるもの ${ }^{3), 4)}$, あるいは両者を取り 入れた半解析的なもの ${ }^{5)}$, 有限要素法の適用によるも $の^{6), 7)}$, そして, CCV に関する設計基準の素案 ${ }^{81}$ など多 くの成果を生んでいる.

このような既往研究のうち, たとえば, 斜め圧縮場理 論 $\left(\right.$ Collins $\left.{ }^{3)}\right)$ やクラックひずみ法 (吉川・田辺 $\left.{ }^{4)}\right)$ は, 変形量と諸耐力の両者が算出されるが, 荷重段階に従っ て順次解き, 収束計算を行う必要がある，有限要素法は 材料の非線形性が比較的自由に表現でき，汎用性におい て優れているが，大型構造物に適用するには大容量の計 算機あるいは適当なモデル化を必要とし, 設計手法とし

* 正会員 工博 (株)間組技術研究所

( ₹338 与野市本町西 4-17-23)

** 正会員 工博 名古屋大学教授 工学部土木工学科 （ \%464 名古屋市千種区不老町）
ては不向きである.

これに対して, 塑性理論 (plastic theory) は終局状 態のみに着目した解析手法であるため変形過程には言及 しないが，簡略した仮定のもとに最大耐力の解析解を与 えるもので，より一般的かつ一貫性のある表示を行える ことが大きな特徴である(このため, 極限解析 (limit analysis) ともよばれることが多い).

塑性理論は, これまで多くの研究者により, 鋼構造お よび岩盤・土質材料において発展し, Nielsen らがコン

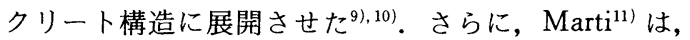
塑性理論を適用する際, tension cut-off を加味した修正 Coulomb 則を導入し, 発展させている.

わが国におけるこの種の研究例としては, 小野・田中 の研究 ${ }^{12)}$ が古くから知られており, 極限解析における上 下界值を厳密に導出している. また, はり・柱部材を対 象とする塑性理論（もしくは極限解析）としては, 南 ${ }^{13)}$, 檜貝 ${ }^{14)}$ の総括論文に詳しく, 無次元量による耐力表示が 多用されている.

特に最近では, 塑性理論はいわゆるマクロ・モデル構 築のための基本理論として導入され，はり部材や耐震壁 に活用されている ${ }^{14), 15)}$. また，日本建築学会耐震設計小 委員会において，せん断設計法に関する従来の実験式に 代わって塑性理論が取り入れられる気運にある ${ }^{16)}$. 
本文は, 解析手法として Nielsen らによる塑性理

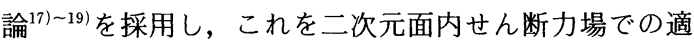
用方法を検討するとともに，13 体の鉄筋コンクリート 円筒ねじり実験から得られた実測結果と照合しようとす るものである.

本文では，3つの無次元量を新たに導入し，関係諸式 をこれらによって表示することを試みた．この結果，塑 性理論から与えられるすべてのせん断耐力の算定式およ び実験結果を，この 3 量で表現することが可能となり， より一般的な評価式に書き換えることができた.

\section{2. 塑性理論による耐力評価式}

\section{（1）基本条件}

塑性理論は,材料を完全剛塑性体に仮定し,コンクリー ト部材の終局時の耐力を算出するもので, 極限解析とも よばれる.このため部材挙動を荷重初期より追跡するこ とはできないが，簡単な材料のモデル化（たとえば，コ ンクリート引張力 $=0$, 鉄筋が降伏状態) により, 終局 時の耐力が解析的に与えられる.これまで, はり部材の せん断, 割裂強度, ブラケット材, 押抜きせん断などの 耐力算定について, 次々と論文が発表され, 広い適用範 囲をもつ ${ }^{9), 10)}$.

塑性理論の理論的根拠となっている Druckerによる 上界定理，下界定理および基本式の定式化については関 連文献を参照するものとし，2. では平面応力場におけ る面内せん断力之軸力の組合せ荷重に対する耐荷機構へ の適用について検討を行い, 次いで3. において, コン クリート生縮強度の有効係数 $\nu$ 導入, 無次元量によ る表示などについて検討を加え，より一般的な取扱いへ の拡張を試みる.

対象とする部材は，図一1 に示すような単位幅の鉄筋 コンクリート平板で, 外力として $X, Y$ 両方向の直応 力 $\sigma_{1}, \sigma_{2}$ とせん断力 $\tau$ が作用する場合を考える. また,

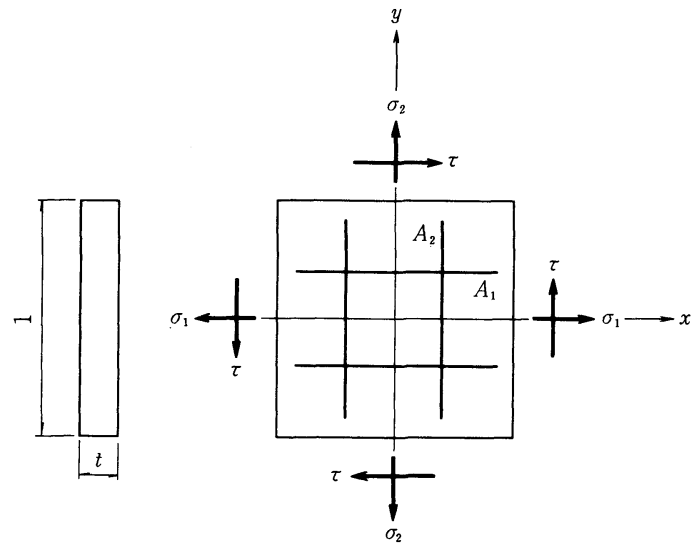

図一1＼cjkstart面内カを受ける直交眍筋の鉄筋コンクリート平板
基本条件として以下を仮定する.

i ）終局時を考え，鉄筋は降伏状態，もしくはコンク リートは引張応力を 0 , 主圧縮応力度が圧縮強度に達し ていると仮定する.

ii）面外方向の変位, 応力は生じないものとし, 厚さ 方向は均一とする.すなわち平面応力場を考える.

iii）引張を正とする.

iv）鉄筋は直交配筋とし，おのおの $X$ 軸， $Y$ 軸に一 致する.

単位幅当たりの鉄筋断面積を $X, Y$ 各方向について $A_{1}, A_{2}$ とすると, 鉄筋比は $p_{1}=A_{1} / t, p_{2}=A_{2} / t$ で表 わされるが，さらに下式のように鉄筋係数 (degree of reinforcement） $\phi$ を定義する（ $t$ は平板の厚さを示す. また, 添字 1 は $X$ 軸方向, 添字 2 は $Y$ 軸方向を意味す るものとし, 添字が省略されているときは $X, Y$ 両方 向を特定しない場合，もしくは等しい場合を示す).

$$
\begin{aligned}
& \psi_{1}=\frac{A_{1}}{t} \cdot \frac{f_{y}}{f_{c}}=\frac{p_{1} f_{y}}{f_{c}} \\
& \psi_{2}=\frac{A_{2}}{t} \cdot \frac{f_{y}}{f_{c}}=\frac{p_{2} f_{y}}{f_{c}}
\end{aligned}
$$

ここで, $f_{y}$ は鉄筋の降伏強度， $f_{c}$ はコンクリートの圧 縮強度を示す. 単位幅当たりの鉄筋は降伏耐力 $A f_{y}$ を もつが,さらに,

$$
\sigma_{e q .1}=\frac{A_{1} f_{y}}{t}=p_{1} f_{y}, \quad \sigma_{e q .2}=\frac{A_{2} f_{y}}{t}=p_{2} f_{y}
$$

を鉄筋の等価応力 (equivalent stress) として定義する. そうすると, 鉄筋係数 $\psi$ は, 鉄筋耐力 $A \cdot f_{y}$ とコンクリー 卜耐力 $t \cdot f_{c}$ の比, もしくは鉄筋の等価応力 $\sigma_{e q}$ とコン クリートの圧縮応力度 $f_{c}$ の比という物理的意味をもつ ことがわかる. この鉄筋係数は, 力学的鉄筋比ともよば れ, 鉄筋コンクリートにおける基本的な力学的無次元量 である。

なお，材料を完全塑性体と仮定しているので，本文で しばしば用いる降伏条件（または降伏曲面）は，最大耐 力もしくは終局耐力と合致するものとする.

\section{（2）内面せん断力の表示}

以上のような基本条件のもとに, 鉄筋コンクリート平 板の単軸強度, 純せん断強度およびせん断力と直応力の 複合応力下での最大耐力式を示す.これらは主に, Nielsen による研究（文献 17），および文献 18)）をも とに，著者らが整理し統一的に表現するとともに，いく つかの解釈を加えたものである. 定式化の詳細な過程に ついては，本文献を参照していただきたい。

まず，直応力のみが作用したとき（図-1で $\tau=0$ ) の鉄筋コンクリート平板の引張強度, 圧縮強度は式( 4$)$, (5) で表わされる.

$$
\sigma_{1}=\psi_{1} \cdot f_{c}, \quad \sigma_{2}=\phi_{2} \cdot f_{c}
$$




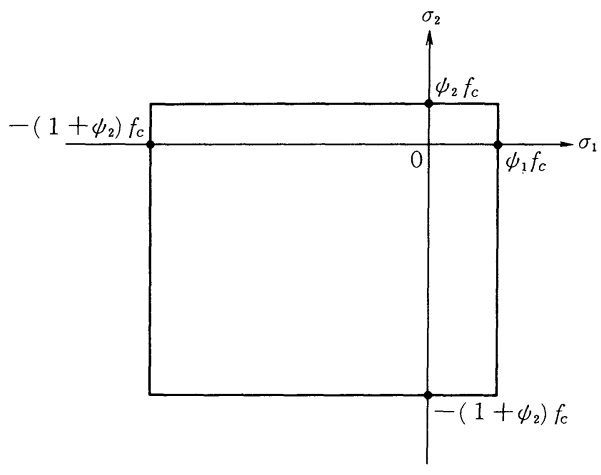

(a) 直応力下 $\left(\sigma_{1}, \sigma_{2}\right)$ の最大耐力

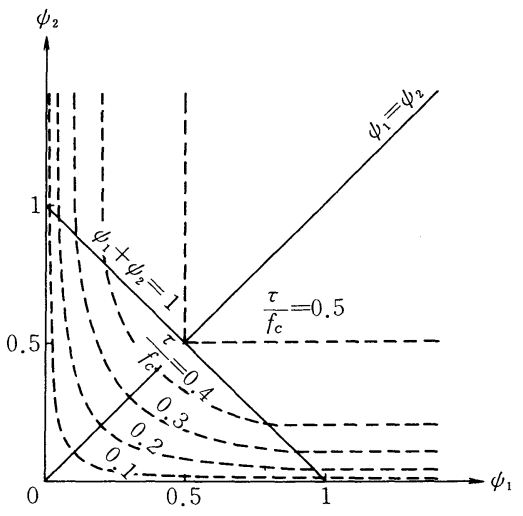

(点線はせん断耐力 $\tau / f_{c}$ の等高線を示す。)

（b）純せん断時の最大耐力

図一2 単純応力状態での鉄筋コンクリート平板の降伏条件

$\sigma_{1}=-\left(1+\psi_{1}\right) f_{c}, \quad \sigma_{2}=-\left(1+\psi_{2}\right) f_{c}$

上式は, 引張強度が, $\phi \cdot f_{c}=p f_{y}$ で鉄筋の等価応力に 等しく, また, 圧縮強度がー $(1+\psi) f_{c}=-\left(f_{c}+p f_{y}\right)$ となっ てコンクリートの圧縮強度と鉄筋の等価応力の和で表わ されていることがわかる．これらを用いると，2 軸直応 力下の最大耐力は図一2(a) のようになり, 単純な矩形 の降伏条件を形成する. 一方, 純せん断時（図一1で $\sigma_{1}$ $\left.=\sigma_{2}=0\right)$ の最大耐力は下式で与えられる.

$$
\begin{aligned}
& \psi_{1}+\psi_{2} \leqq 1 \text { のとき } \\
& \quad \tau=\sqrt{\psi_{1} \psi_{2}} f_{c}=\sqrt{p_{1} f_{y^{*}} p_{2} f_{y}}
\end{aligned}
$$

$\psi_{1}+\phi_{2}>1$ のとき

$$
\begin{array}{ll}
\tau=\sqrt{\psi_{1}\left(1-\phi_{1}\right)} f_{c} & \left(\phi_{1}<0.5<\phi_{2}\right) . \\
\tau=\sqrt{\psi_{2}\left(1-\psi_{2}\right)} f_{c} & \left(\phi_{2}<0.5<\phi_{1}\right)
\end{array}
$$

$\psi_{1}, \psi_{2}>0.5$ のとき

$$
\tau=\frac{1}{2} f_{c}
$$

このときのせん断耐力を図一2(b) に示す.図中では 無次元量 $\tau / f_{c}$ を用い, これを等高線によって表示して いる. 式 (6) は両鉄筋の等価応力で表わされ, 式 (9) は鉄筋量に関係なくコンクリート強度のみで決定される ことを示している. 式 $(7),(8)$ は $\psi_{1}$ と $\psi_{2}$ のうち小 さい方の方向の鉄筋降伏が先行し，これによって最大せ ん断力が決定されることを意味する.

さらに，図一1のように，直応力 $\sigma_{1}, \sigma_{2}$ が作用したと きの一般的な最大せん断力 $\tau$ に関する降伏条件を式 (10)〜（13）に，このときの降伏曲面を図一3に示す. ただし，ここでは $X, Y$ 両方向の鉄筋量を同一とし， $\psi_{1}$ $=\phi_{2}=\psi$ の場合について示す.

図一3に示すように，降伏条件は $\sigma_{1}$ と $\sigma_{2}$ の大きさと 破壊モードにより，5つの領域に分けられる.

- 領域 I (BLG) : $\sigma_{1}+\sigma_{2} \geqq-(1-2 \psi) f_{c}, \sigma_{1}, \sigma_{2} \leqq \psi f_{c}$

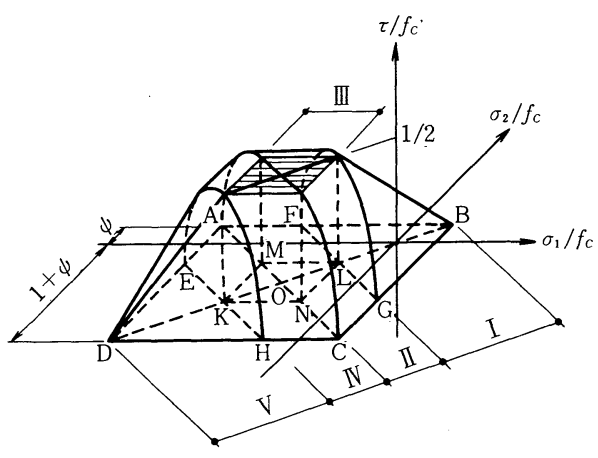

(a) 降伏曲面による表示

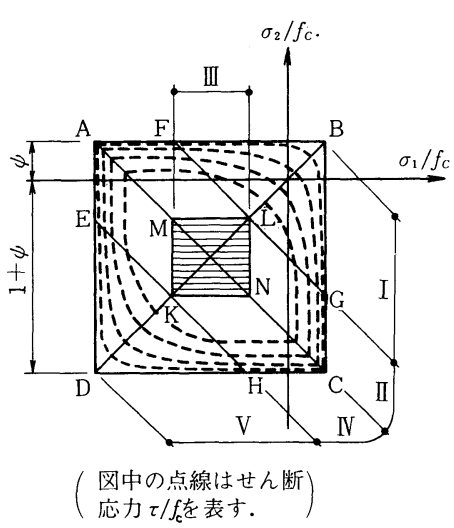

（b）等高線による表示

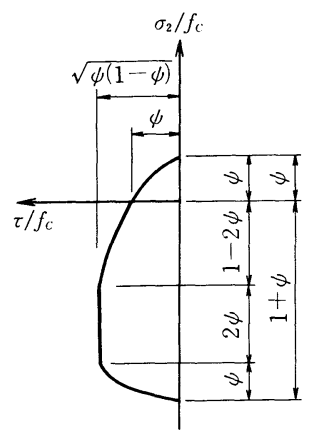

(c) $\sigma_{1}=0$ のときの降伏曲線

図一3 鉄筋コンクリートの面内力に対する降伏条件 $(X, Y$ 方向等量配筋) 
$\tau=\sqrt{\left(\psi f_{c}-\sigma_{1}\right)\left(\psi f_{c}-\sigma_{2}\right)}$

- 領域 II (LGCN) : $-(1-2 \psi) f_{c}>\sigma_{1}+\sigma_{2} \geqq-f_{c}$,

$$
\sigma_{1} \geqq-\left(\frac{1}{2}-\psi\right) f_{c}
$$

$\tau=\sqrt{\left(\phi f_{c}-\sigma_{1}\right)\left\{(1-\phi) f_{c}+\sigma_{1}\right\}}$

または，

$$
\left(\frac{\tau}{f_{c}}\right)^{2}+\left\{\frac{\sigma_{1}}{f_{c}}-\left(\psi-\frac{1}{2}\right)\right\}^{2}=\left(\frac{1}{2}\right)^{2} .
$$

• 領域III (LNKM) :

$$
-\left(\frac{1}{2}-\psi\right) f_{c}>\sigma_{1}, \quad \sigma_{2}>-\left(\frac{1}{2}+\psi\right) f_{c}
$$

$\tau=\frac{1}{2} f_{c}$

- 領域IV (NCHK) : $-f_{c}>\sigma_{1}+\sigma_{2} \geqq-(1+2 \psi) f_{c}$,

$$
\sigma_{2} \leqq-\left(\frac{1}{2}+\psi\right) f_{c}
$$

または，

$$
\left(\frac{\tau}{f_{c}}\right)^{2}+\left\{\frac{\sigma_{2}}{f_{c}}+\left(\frac{1}{2}+\psi\right)\right\}^{2}=\left(\frac{1}{2}\right)^{2}
$$

- 領域 $\mathrm{V}(\mathrm{DKH}):-(1+2 \psi) f_{c}>\sigma_{1}+\sigma_{2}$

$\tau=\sqrt{\left.\left.\left\{(1+\psi) f_{c}+\sigma_{1}\right\}\right\}(1+\psi) f_{c}+\sigma_{2}\right\}}$

$X, Y$ 両方向の鉄筋が同量であるため，上式は， $\sigma_{1} \geqq$ $\sigma_{2}$ (直線 BD の右下部分) の場合について示し, 図一 3 はこれらを $f_{c}$ によって正規化した無次元量によって図 示している.

さらに，式（10)〜 (14) および図一3に関して，次の ような解釈を与えることができる. 領域 I は鉄筋の引張 降伏のみで耐力が決定し, 対称的に領域 $\mathrm{V}$ は両鉄筋が圧

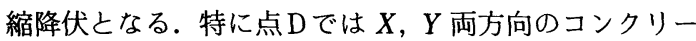
卜応力も圧縮強度に達している. 式 (10) で $\sigma_{1}=\sigma_{2}=0$ とすると式（6）に，式（14）で $\tau=0$ とすると式（5） に帰着する。

領域 II IV はこれらの中間にあり，一方の鉄筋が圧縮 降伏, または引張降伏の状態で, $\sigma_{1}=\sigma_{2}=0$ とすると式 （11）は式（7）もしくは式（8）に帰着する.

領域III $f_{c}$ のみで決定する領域で, 鉄筋係数 $\psi$ に依 存しない。これは, いわゆる over-reinforced とよばれ る補強限界を示すもので, 式 (12) で与えられる.

底面の正方形 $\mathrm{ABCD}$ の線上は $\tau=0$ であり， $\sigma_{1}$ と $\sigma_{2}$ のみによる降伏条件を表わすが，これは図一2(a)で廿 $=\psi_{1}=\psi_{2}$ としたときに一致する.

また，幾何学的には次のような解釈を与えることがで きる. 領域 I とVは BD を主軸とする円錐形となり， 領域 II と $\mathbb{N}$ は，それぞれ $\sigma_{2} / f_{c}$ 軸， $\sigma_{1} / f_{c}$ 軸を中心軸と する円筒形で表わされる，領域は，これらをつなぐ底 面に平行な平面で，あらゆる $\sigma_{1}$ と $\sigma_{2}$ の組合せのうちで 最大值を示す。
以上までが，Nielsenによる評価式（降伏条件）を整 理し，若干の説明を加えたものである.これによって， 図一1 に示す任意の面内力を受ける鉄筋コンクリート平 板の降伏条件が統一的に表わされ，各領域の特徴が明碓 になったといえる。

一般に塑性理論は構成材料を単純な剛塑性体に仮定 し，最大耐力に関する解析解を求めようとするものであ る.このため，鉄筋コンクリートに特有な付着破壊やひ びわれ面でのせん断伝達を塑性理論に取り入れようとす る之, 支配方程式の数が不足し，陽な解析解を得られな い場合が多い。したがって，塑性理論は整然とした解析 解を与えてくれる反面，局所的な非線形現象を反映しに くい面をもつといえる.

本文では，さらに配筋方向の影響，コンクリートの有 効係数の導入，無次元量による表示について，考察を進 めるものとする.

\section{（3）配筋方向の影䈉}

本理論を一般化するには任意の鉄筋方向と鉄筋交角に ついて言及する必要がある，本文では，直交配筋を前提 とし， $\psi_{1}=\phi_{2}$ の場合にのみ降伏条件が鉄筋方向 $\alpha$ に無 関係となることを説明するにとどめる.

図一4に示すように，鉄筋の配筋方向と座標軸 $X-Y$

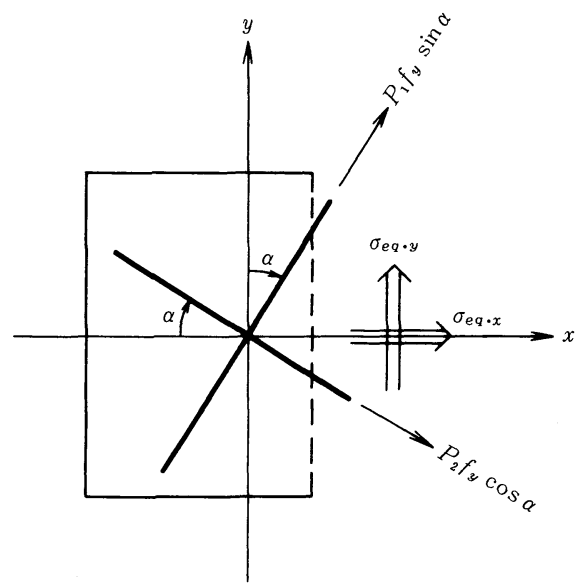

図一4任意の配筋方向に対する鉄筋の等価応力

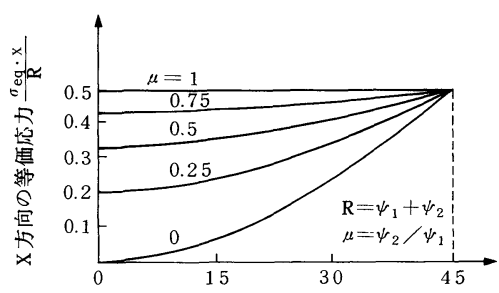

鉄筋の配筋方向 $\alpha$ (deg.）

図一5 鉄筋の配筋方向と等価応力との関係 
との角度を $\alpha$ とする $(0 \leqq \alpha \leqq \pi / 4)$. このときの鉄筋応 力は有効面積を考慮すると, $p_{1} f_{y} \sin \alpha, p_{2} f_{y} \cos \alpha$ と なるが，これら両鉄筋の $X$ 軸と $Y$ 軸方向への等価応力 を算出すると以下のようになる.

$$
\sigma_{e q . X}=p_{1} f_{y} \sin ^{2} \alpha+p_{2} f_{y} \cos ^{2} \alpha \text {. }
$$

$\sigma_{e q . Y}=p_{1} f_{y} \sin \alpha \cos \alpha-p_{2} f_{y} \sin \alpha \cos \alpha$

ここで, $p_{1}=p_{2}=p$ とすると上式は

$$
\begin{aligned}
\sigma_{\text {eq.X }} & =p f_{y} . \\
\sigma_{\text {eq.Y }} & =0 \cdots
\end{aligned}
$$

となり，鉄筋方向 $\alpha$ に無関係で等価応力が一定となる. すなわち, 2 方向の鉄筋係数が同じとき, 鉄筋コンクリー 卜平板の異方性は消失し, 式 $(10) \sim(14)$ は任意の鉄筋 方向に対して有効であることがわかる. また，両方向の 鉄筋係数（または鉄筋化）の比 $\mu$ を

$$
\mu=\frac{\psi_{2}}{\phi_{1}}=\frac{p_{2}}{p_{1}} \quad(0 \leqq \mu \leqq 1)
$$

のように定義し, 両方向の鉄筋の合計 $R$ を一定とした ときの, $\sigma_{e q . X}$ の変化を調べる.すなわち,

$$
\begin{aligned}
R= & p_{1} f_{y}+p_{2} f_{y}=(1+\mu) p_{1} f_{y} \cdots \\
\sigma_{e q . X} & =\left(\sin ^{2} \alpha+\mu \cos ^{2} \alpha\right) p_{1} f_{y} \\
& =\frac{1-(1-\mu) \cos ^{2} \alpha}{1+\mu} R
\end{aligned}
$$

上式を使って， $\mu$ をパラメーターとしたときの $\sigma_{e q . x} / R$ と $\alpha$ の関係を図一5に示す. 同図からわかるよ うに, $\alpha=45^{\circ}$ のとき $\sigma_{e q . X}$ は最大となり, $\mu=1\left(p_{1}=p_{2}\right)$ では $\alpha$ に依存せず一定值となっている.

\section{3. 一般化への拡張}

\section{（1）無次元量による表示}

式 (1)，（2）で定義した鉄筋係数 $\phi$ に加えて, 次の
ようなせん断応力と軸応力に関する無次元量を定義す る.

$$
\begin{aligned}
& \eta=\frac{\tau}{f_{c}} \cdots \cdots \cdots \cdots \\
& \xi_{1}=\frac{\sigma_{1}}{f_{c}}, \quad \xi_{2}=\frac{\sigma_{2}}{f_{c}}
\end{aligned}
$$

すなわち, $\eta, \xi$ および $\phi$ はいずれもコンクリートの圧 縮強度によって正規化したもので，これら 3 量を用いた 降伏条件式の記述を以下に示す（鉄筋係数 $\phi$ および軸 応力に関する無次元量 $\xi$ は, $X, Y$ 方向で異なる場合, おのおの $\psi_{1}, \psi_{2}$ あるいは $\xi_{1}, \xi_{2}$ のように添字をつけ, 区 別する).

領域 I : $\xi_{1}+\xi_{2} \geqq-(1-2 \psi)$

$$
\eta=\sqrt{\left(\phi-\xi_{1}\right)\left(\phi-\xi_{2}\right)}
$$

領域 II : $-1 \leqq \xi_{1}+\xi_{2} \leqq-(1-2 \psi), \xi_{1} \geqq-\left(\frac{1}{2}-\psi\right)$

$$
\eta=\sqrt{\left(\psi-\xi_{1}\right)\left\{1-\left(\psi-\xi_{1}\right)\right\}}
$$

領域 III : $-\left(\frac{1}{2}+\psi\right) \leqq \xi_{1}, \xi_{2} \leqq-\left(\frac{1}{2}-\psi\right)$

$$
\eta=\frac{1}{2}
$$

領域IV : $-(1+2 \phi) \leqq \xi_{1}+\xi_{2} \leqq-1, \xi_{2} \leqq-\left(\frac{1}{2}+\psi\right)$

$$
\eta=\sqrt{-\left(\phi+\xi_{2}\right)\left(1+\psi+\xi_{2}\right)}
$$

領域 $\mathrm{V}: \xi_{1}+\xi_{2}<-(1+2 \psi)$

$$
\eta=\sqrt{\left(1+\psi+\xi_{1}\right)\left(1+\psi+\xi_{2}\right)}
$$

これらのうち, 領域 I, II , IIIに着目し図示すると, 図一6に示すような $\phi \sim \xi \sim \eta$ 曲線が得られる(一般に 通常の設計条件もしくは既往の実証実験の範囲では領域 IV，Vに相当する破壊モードは存在せず，もっぱら領域 I, II, IIIが研究対象となっている). また,ここでは軸

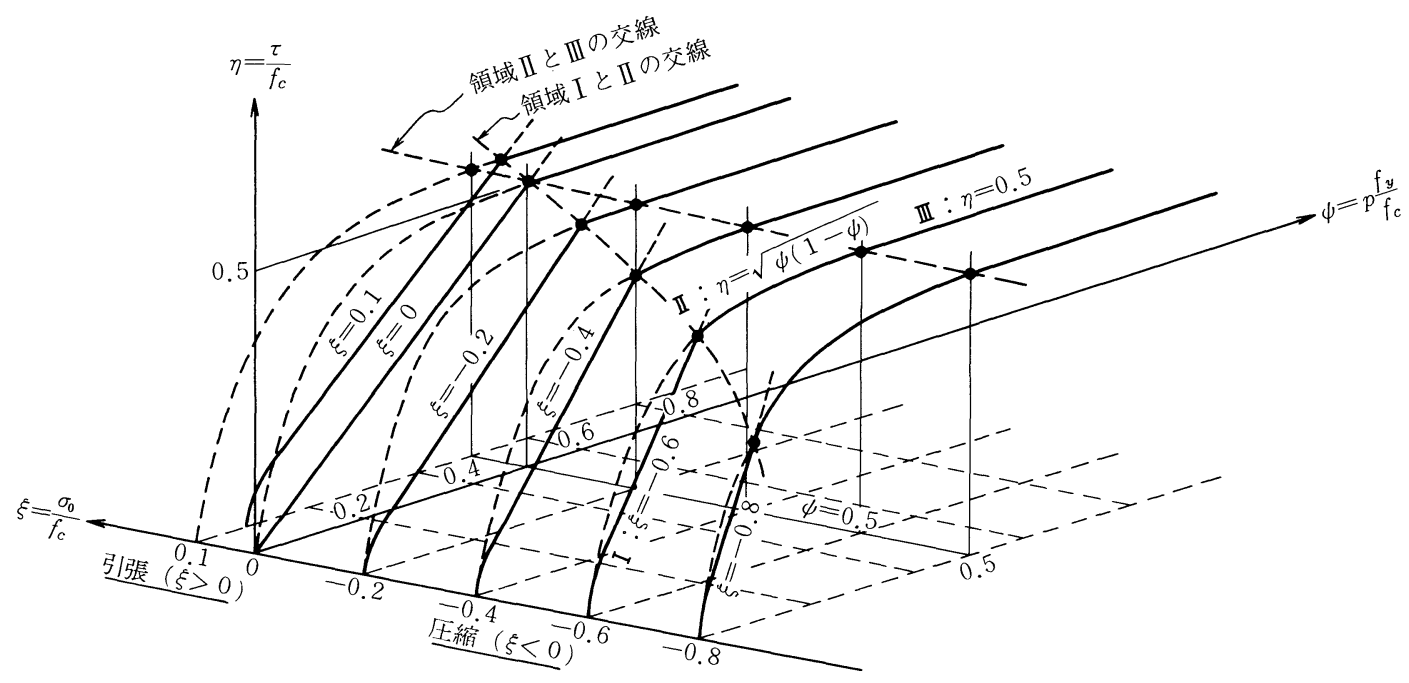

図一6 鉄筋係数と軸応力とせん断耐力の関係 $(\phi \sim \xi \sim \eta$ 曲線 $)$ 
応力は一方向のみに作用している場合を考えている.

これによって軸応力 $\sigma$ と鉄筋比 $p$ が与えられたとき の面内せん断耐力 $\tau$ が, 任意の材料強度 $f_{c}, f_{y}$ に対し て決定されたことになる.

\section{（2）有効係数 $\nu$ の導入}

領域 II ，IIIのようにコンクリートの圧縮破壊を伴うよ うな破壊モードでは，その圧縮強度を適切に設定する必 要がある．すなわち，部材内の圧縮斜材の最大応力が， 標準供試体による単軸試験から得られた $f_{c}$ より小さい 值で破壊に至っていることが実験的に観測され，多くの 研究者より指摘されている20) 22).

そこで, 2, 3 の研究者は, コンクリートの圧縮強度に 関する有効係数 (effectiveness factor) $\nu$ を用い,

$$
f_{c} \rightarrow \nu \cdot f_{c} \quad(0<\nu<1)
$$

と置き換えることを提案している(19),23). これを式 (22) （24）に導入すると，次式のように書き換えられる. 領域 I : $\xi_{1}+\xi_{2} \geqq-(\nu-2 \psi)$

$$
\eta=\sqrt{\left(\phi-\xi_{1}\right)\left(\psi-\xi_{2}\right)}
$$

領域 II : $-\nu \leqq \xi_{1}+\xi_{2} \leqq-(\nu-2 \psi), \xi_{1} \geqq-\left(\frac{1}{2} \nu-\psi\right)$

$$
\eta=\sqrt{\left(\psi-\xi_{1}\right)\left\{\nu-\left(\psi-\xi_{1}\right)\right\}}
$$

領域 III : $-\left(\frac{1}{2} \nu+\psi\right) \leqq \xi_{1}, \xi_{2} \leqq-\left(\frac{1}{2} \nu-\psi\right)$

$$
\eta=\frac{1}{2} \nu
$$

これら諸式に関して一方向軸力の場合 $\left(\xi_{1}=\xi_{0}, \xi_{2}=0\right)$ について, $\xi_{0} \sim \eta$ 曲線, $\psi \sim \eta$ 曲線を, 図一7(a), (b) のごとく図示することができる，すなわち，図一6に有

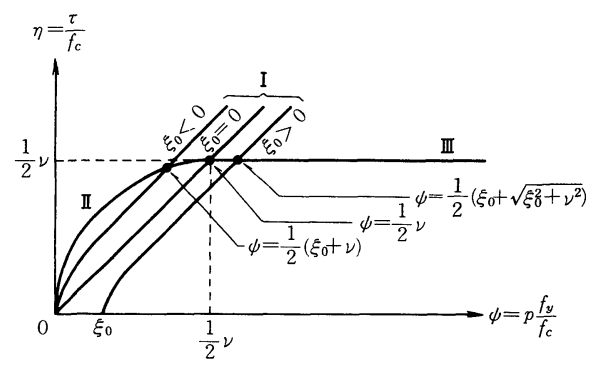

(a) $\psi-\eta$ 曲線 $\left(\xi_{0}=-\right.$ 一定 $)$

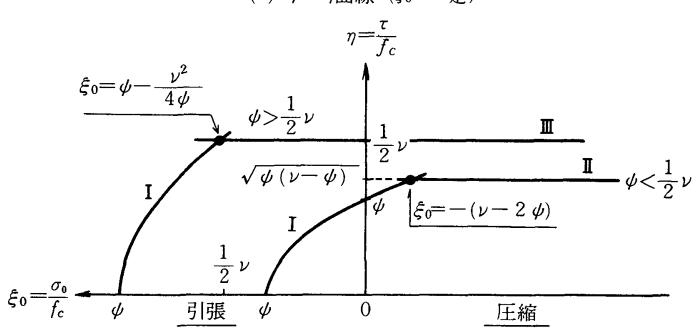

(b) $\xi_{0}-\eta$ 曲線 $(\phi=$ 一定 $)$

図一7 有効係数 $\nu$ を用いたときのせん断耐力（一方向軸力の み作用の場合）
効係数 $\nu$ 考慮し，二次元的に描いたものである.

\section{4. 実測結果との比較}

本文で用いる実験結果は，薄肉中空円筒供試体による 鈶直載荷とねじり加力を組み合わせたもので, 面内力と して一方向軸力とせん断力を再現できる ${ }^{2)}$. 図一8に試 験体の概要および図一-9に加力装置を示す．ここでは, 鉄筋比 $p$ と軸応力 $\sigma_{0}$ をパラメーターとし, 表一 1 に示

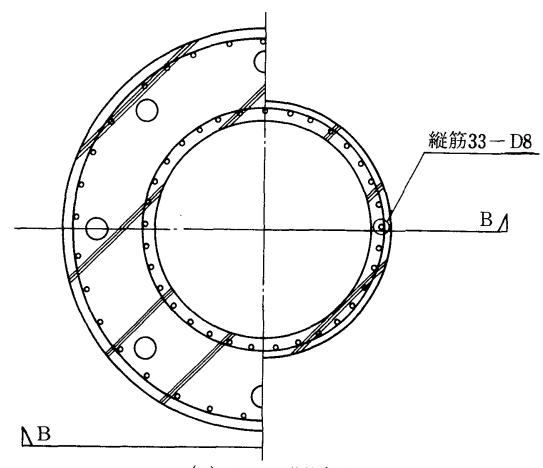

(b) A-A 断面図

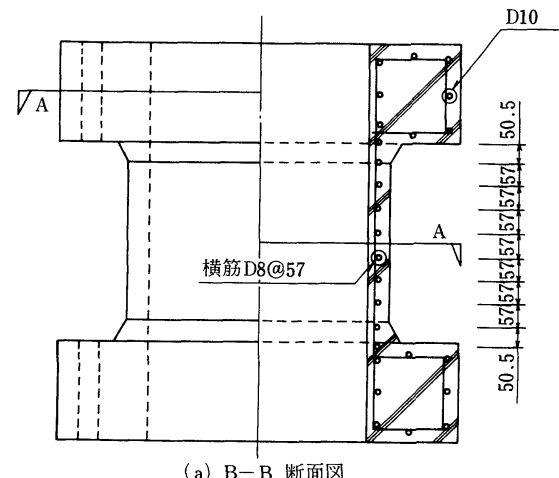

(a) B-B 断面図

図一8 円筒ねじり実験に用いた試験体の概要（ $p=1.75 \%$ の

\begin{tabular}{|c|c|c|c|c|c|c|c|c|}
\hline \multirow{2}{*}{$\begin{array}{c}\text { 武釦体 } \\
\text { No. }\end{array}$} & \multirow{2}{*}{$\begin{array}{c}\text { 縮強度 } \\
f_{\mathrm{c}} \\
\left(\mathrm{kg} / \mathrm{cm}^{2}\right)\end{array}$} & \multicolumn{2}{|l|}{ 鉄 } & \multicolumn{2}{|l|}{ 軸 } & \multicolumn{3}{|c|}{ 世ん断酎力 } \\
\hline & & $\begin{array}{c}\text { 鉄筋比 } p \\
(\%)\end{array}$ & $\begin{array}{c}\text { 鉄筋係数 } \\
4\end{array}$ & $\begin{array}{l}\text { 軸底力 } \sigma_{0} \\
\left(\mathrm{~kg} / / \mathrm{cm}^{2}\right)\end{array}$ & $\xi$ & $\begin{array}{l}\text { せん断柇力 } \\
\tau\left(\mathrm{kgf} / \mathrm{cm}^{2}\right)\end{array}$ & $\eta={ }_{\tau} / f_{c}$ & mode \\
\hline 0 & 229 & 1.01 & 0.1998 & 0 & 0 & 40.3 & 0.176 & $\mathrm{R}$ \\
\hline 1 & 208 & 1.01 & 0.2200 & 0 & 0 & 46.7 & 0.225 & $\mathrm{R}$ \\
\hline 2 & 213 & 1.75 & 0.3722 & 0 & 0 & 61.9 & 0.291 & C \\
\hline 3 & 250 & 2. 44 & 0.4421 & 0 & 0 & 62.8 & 0.251 & $\mathrm{C}$ \\
\hline 4 & 181 & 1.01 & 0.2528 & -50 & -0.276 & 51.5 & 0.285 & $\mathrm{R}^{\prime}$ \\
\hline 5 & 199 & 1.75 & 0.3984 & -50 & -0.251 & 61.7 & 0.310 & C \\
\hline 6 & 202 & 2. 44 & 0.5472 & -50 & -0.248 & 72.3 & 0.358 & C \\
\hline 7 & 220 & 1.01 & 0.2080 & -100 & -0.455 & 63.9 & 0.290 & C \\
\hline 8 & 233 & 1.75 & 0.3402 & -100 & -0.429 & 69.0 & 0.296 & $\mathrm{C}$ \\
\hline 9 & 215 & 2.44 & 0.5141 & -100 & -0.465 & 79.5 & 0.370 & C \\
\hline 10 & 265 & 1.01 & 0.1727 & 25 & 0.094 & 33.8 & 0.128 & $\mathrm{R}$ \\
\hline 11 & 186 & 1.75 & 0.4262 & 25 & 0.134 & 56.5 & 0.304 & $\mathrm{R}^{\prime}$ \\
\hline 12 & 183 & 2. 44 & 0.6040 & 25 & 0.137 & 58.8 & 0.321 & C \\
\hline
\end{tabular}
場合 $)^{2)}$

表一1 鉄筋コンクリート円筒ねじり実験の結果 ${ }^{2)} と そ の$ 無次元 諸量

$\mathrm{R}: 2$ 方向の鉄筋降伏先行, $\mathrm{R}^{\prime}: 1$ 方向の鉄筋降伏先行, $\mathrm{C}:$ コンクリート圧壊型 

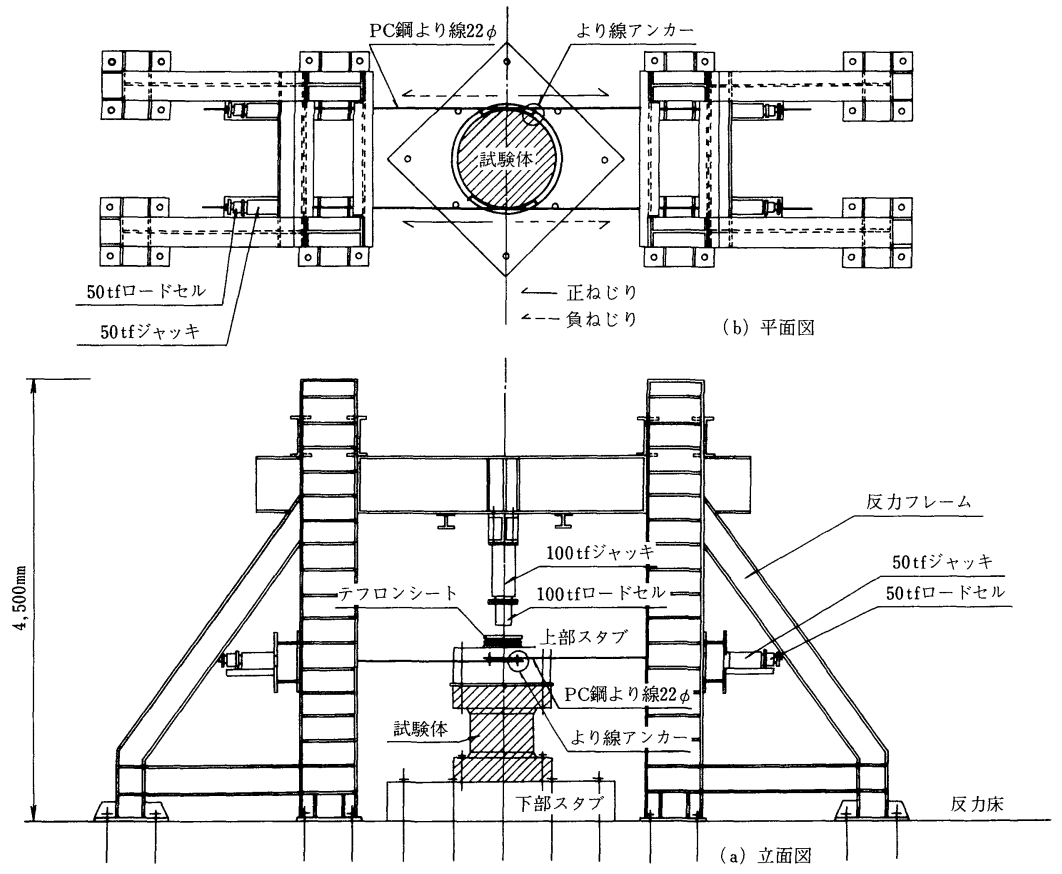

图一9 円筒ねじり実験における加力装置2)

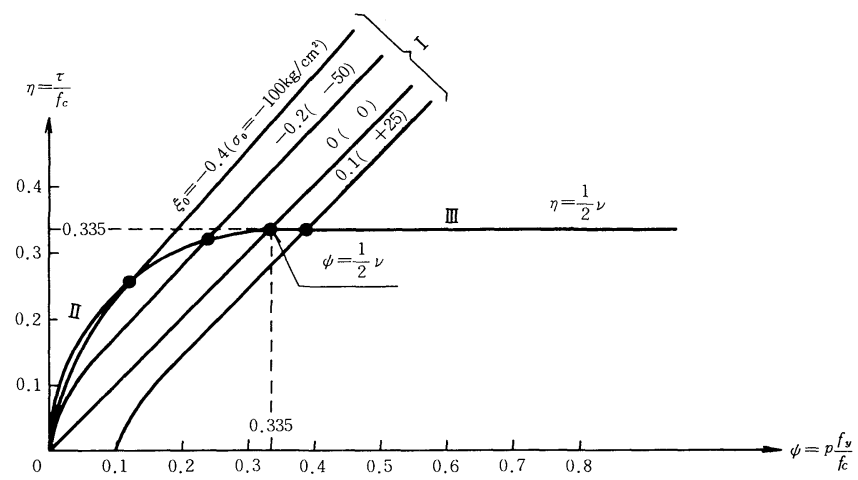

(a) $\psi \sim \eta$ 曲線 $\left(\xi_{0}=-0.4,-0.2,0,0.1\right)$

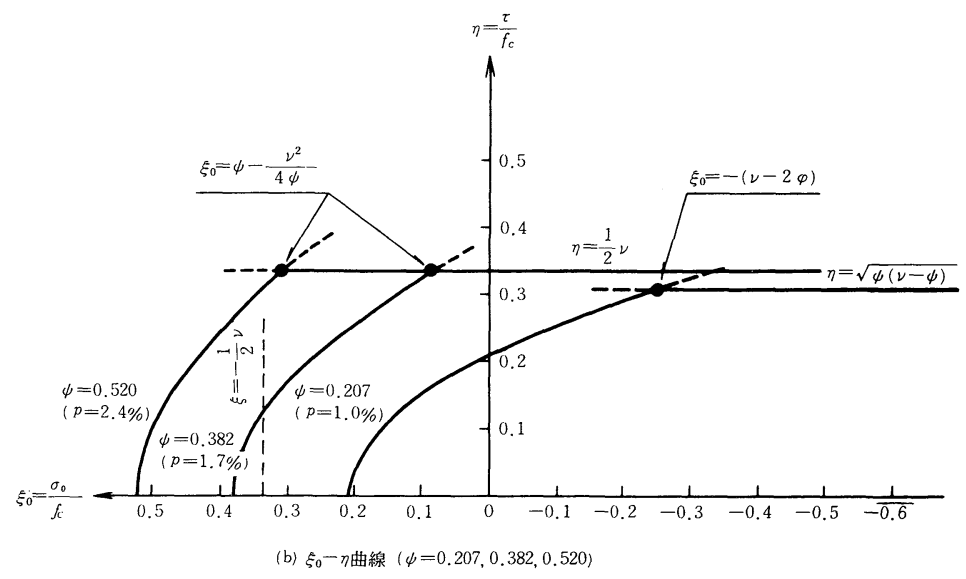

図一10 塑性理論による本算定式の実験結果 $\left.{ }^{2}\right)$ への適用 $(\boldsymbol{\nu}=2 / 3$ と仮定 $)$ 
すように 13 体の試験体について実施したものである. 各供試体の形状，壁厚は同寸法で，2 方向を同量鉄筋之 し，直交配置されている．また，使用した異形鉄筋はい ずれも D8（GRADE 60）で，単鉄筋配置とした。一定 の軸圧縮力または軸引張力のもとに, 正負交番ねじり載 荷を数サイクル与え, 正ねじりにて崩壊させた.

表一1にはこれらの実測結果と本文で用いる諸係数 (無次元量) を示した. 試験方法, 試験結果の詳細につ いては，文献 2) を参照していただきたい.

本理論の適用に際しては，まずコンクリート圧縮強度 の有効係数 $\nu$ を仮定する必要がある. 有効係数 $\nu$ の実 験式については, Braestrup ${ }^{19)}$, 檜貝 ${ }^{24)}$, Exner ${ }^{25)}$ などの 多くの提案があり， $f_{\mathrm{c}}$ の増加とともに有効係数 $\nu$ が減 少していることが基本的に共通している. これらの詳細 な検討は別の機会 ${ }^{26)}$ で論ずるとして，ここでは取り上げ た実測結果とよく合致するように $\nu=2 / 3$ の一定值を仮 定する.

この值を使って, 式 $(27) \sim(29)$ に代入し, 本実験に 適用すると図一10を得る，すなわち， 4 (鉄筋量) につ いて 3 段階， $\xi_{0}$ (軸応力）について 4 段階の組合せに関 して本実験が実施されている（表一1 参照).

次に, 塑性理論と実測結果との比較を $\xi_{0} \sim \eta$ 曲線につ いて図一11に， $\psi \sim \eta$ 曲線について図一12に示す. 図 -11の $\psi$ は図中の試験体の平均値, 図一12の $\xi_{0}$ は $f_{c}$ を目標強度 $\left(250 \mathrm{kgf} / \mathrm{cm}^{2}\right)$ としたときの公称值を用いた.

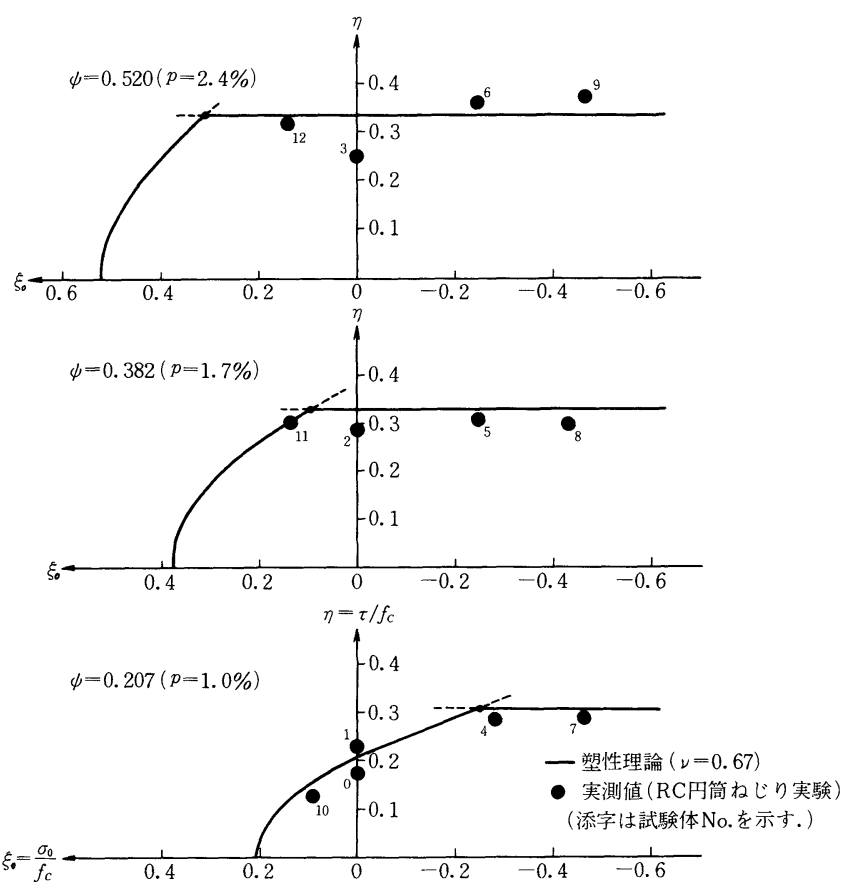

図一11望性理論と実験結果との比較 $\left(\xi_{0} \sim \eta\right.$ 関係 $)$
いずれも理論値と実測值は大略一致し，実測值との変動 係数は $10.7 \%$ であった. 特に, 鉄筋比の増大, 軸応力 の減少（引張を正としている）によって, 面内せん断耐 力が増加し，やがて頭打ちとなる状況をよく説明してい るといえる.

図一13 は両者の比を示したものであるが，No. 3 を除 いて $15 \%$ 以内の誤差となっている. また，破壊モード もほぼ一致しており，たとえば, 理論上領域 I となって いる No. 0, No. 1, No.10の試験体は実験結果でも両鉄 筋の降伏先行 $(\mathrm{R})$ となっており, 領域吕となっている ものはほとんどがコンクリートの圧縮破壊型 (C) を示 している.

しかし，領域 II， IIIの方がややばらつきが大きく，有 効係数 $\nu$ の气え方で算定値が大きく異なり，注意を要 する. 仮定条件の不十分さや理論上十分反映されない点 をすべて有効係数の大小によって補完させようとするこ とは, 塑性理論の構築過程においてやむを得ない点もあ る反面, やや無理があると思われる.したがってレの 評価も含めて, 領域 II , III の領域での算定手法には再検 討が必要と思われる.
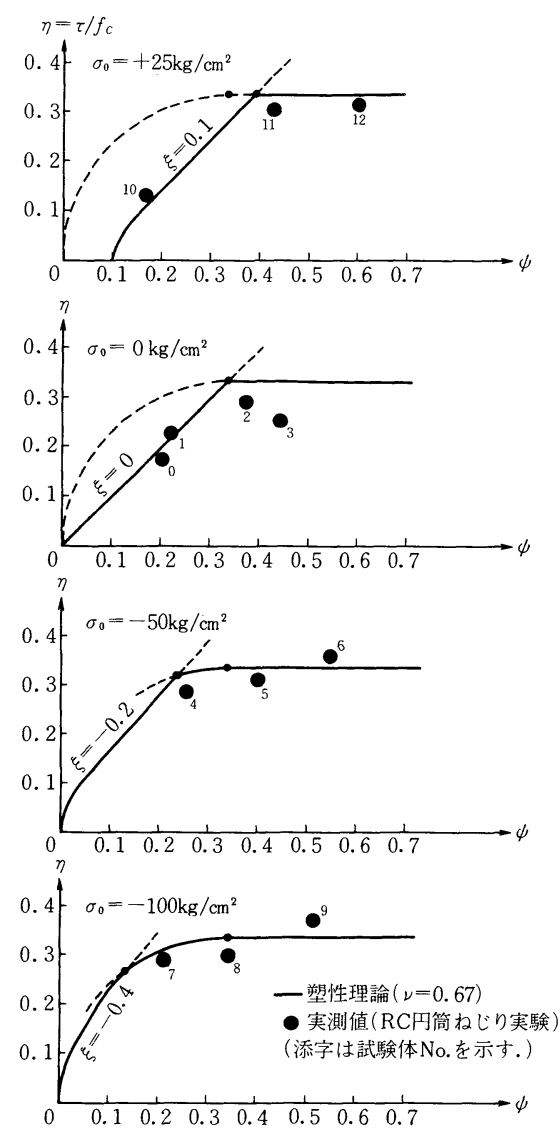

図一12 望性理論と実験結果との比較 $(\psi \sim \eta$ 関係 $)$ 


\section{5. 結 論}

以上のような考察に基づき, 本論の結論として次のよ うにまとめる.

（1） Nielsen らによって提案された塑性理論を採用 して鉄筋コンクリート平板の面内せん断耐力に関する評 価手法を示すとともに, 著者らによる力学的解釈を付与 した.このことによって破壊モードによって分類される 5 つの降伏条件を明瞭に再現したといえる. しかし, 塑 性理論は簡便な材料仮定から出発し, 解析解 (閉解) を 目指すものであり，定着・付着破壊やひびわれ界面のせ ん断伝達など局所的な現象は取り入れにくいことを指摘 した.

（2）さらに, 無次元量による表示, コンクリートの 有効係数の導入を試み，同理論をより一般的・現実的な 評価式に発展させた.このことによりすべての降伏条件 を 3 種の無次元量 $\eta, \xi$ および $\psi$ によって簡潔に記述す ることが可能となった。

また，縦・横両方向の鉄筋係数が等しいときに限り， 鉄筋方向による異方性はなくなり, 直交配筋であれば本 理論で与えられる諸式が任意の配筋方向に対して成立す ることが判明した.

（3）本算定式を軸応力と鉄筋量をパラメーターとす る 13 体の鉄筋コンクリート円筒ねじり実験の実測結果 と照合した. その結果, 両者はよく一致し, 特に, 面内 せん断耐力が鉄筋量や軸応力の変化によって頭打ち現象 となることをよく説明している。しかし，コンクリート の圧縮破壊が先行する領域 III，IIIではやや不十分で，こ れはコンクリート圧縮強度の有効係数 $\nu$ についてら に検討を必要とするものである.

\section{6. あとがき}

コンクリート部材の崩壊に至るまでのせん断挙動は, きわめて複雑で多くの要因に支配され, より詳細な解析 が必要とされる. 最近の研究は, 有限要素法の発展と相 まって, ひびわれ面のせん断伝達機構, 鉄筋の付着やダ ボ作用の検討なよ゙, よりミクロな方向に向かいつつある ように思われる.

一方これとは逆に，より単純な仮定のもとに一般性を 失うことなく降伏条件を定め, 部材レベルから構造系へ の解析に発展させることも肝要である. 特に, 設計面へ の応用,一般構造の算定手法につながることが望ましい. 著者らはこのような観点から塑性理論を採用し, 面内力 を受ける平板問題への適用性について考察した。

\section{記 号}

本文で用いた主要記号を次のようにまとめる. 添字 $1,2: X$ 軸方向, $Y$ 軸方向を示す

$A_{1}, A_{2}$ : 単位幅当たりの鉄筋量

$t:$ 平板の厚さ

$p_{1}, p_{2}$ : 鉄筋比 $p=A / t$

$\psi_{1}, \psi_{2}:$ 鉄筋係数 $\psi=p f_{y} / f_{c}$

$f_{c}$ : コンクリートの圧縮強度(標準供試体による)

$f_{y}:$ 鉄筋の降伏強度

$\sigma_{e q}$ : 鉄筋の等価応力 $\sigma_{e q}=p f_{y}$

$\sigma_{1}, \sigma_{2}$ : 平板に作用する軸応力

$\tau$ : 平板に作用するせん断応力

$\mu$ :両方向鉄筋量 (鉄筋係数) の比 $\mu=\psi_{2} / \psi_{1}=p_{2} / p_{1}$

$R$ : 両方向鉄筋係数の和 $R=\phi_{1}+\phi_{2}$ $\sigma_{0}$ : 一方向のみ作用するときの軸応力

$\nu$ : コンクリート圧縮強度の有効係数

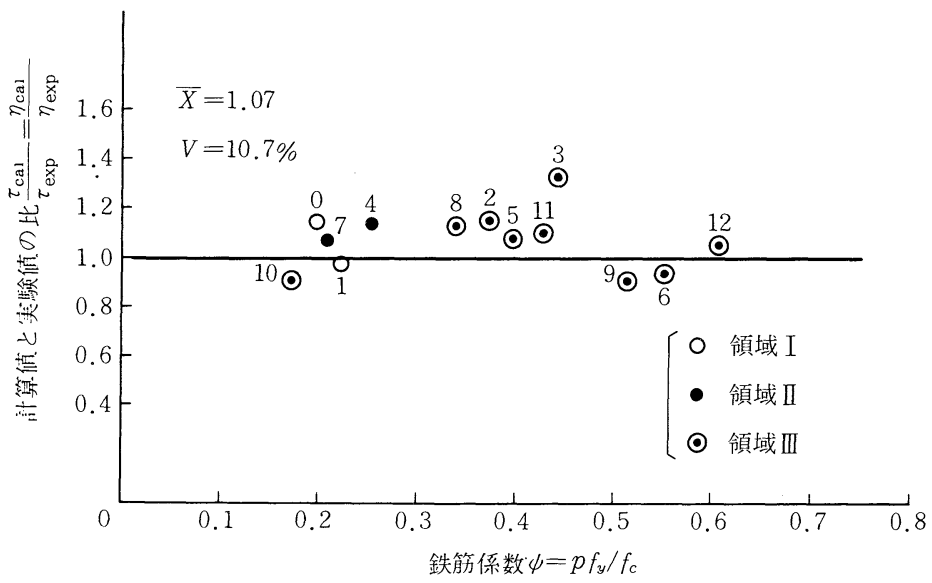

図一13塑性理論による計算值と実倹結果との比較 
$\xi$ : 軸応力に関する無次元量 $\xi=\sigma / f_{c}$

$\eta$ : せん断耐力に関する無次元量 $\eta=\tau / f_{c}$

\section{参 考 文 献}

1）六車 熙・渡辺史夫・藤井正則：せん断力を受ける鉄筋 コンクリート壁の力学的性質に関する実験研究, 第 6 回 コンクリート工学年次講演会論文集, 日本コンクリート 工学協会, pp. 705 708, 昭 59.7.

2）吉川弘道 - 飯田 㓮 - 角 一行 - 中川晶夫 - 山縣博士： コンクリート製格納容器のせん断挙動に関する研究，(そ の 1）鉄筋コンクリート円筒体のねじり加力実験, 間組 研究年報（1982 年版）pp. 157 173，昭 58.4.

3) Collins, M. P. : Towards a Rational Theory for RC Members in Shear, ASCE. ST4, Vol.104, pp.649 666, April 1978.

4）吉川弘道・田辺忠顥：ひびわれを有する鉄筋コンクリー 卜板の平面応力場における構成方程式, コンクリート工 学 (論文), Vol.24, No.6, 日本コンクリート工学協会, pp. 93 110, 昭 61.6 .

5）吉川弘道・梅原秀哲・田辺忠顕：面内せん断力を受ける 鉄筋コンクリート平板に関する破壊モードの推定ならび に終局耐力式の提案, 土木学会論文集, 第 360 号 $/ \mathrm{V}-3$, pp. 139 - 145, 昭 60.8 .

6) 岡村 甫・前川宏一：コンクリート構造物の有限要素解 析における解析モデルの評価, $\mathrm{RC}$ 構造の有限要素解析 に関するコロキウム論文集, 日本コンクリート工学協会, pp. 139 - 146, 昭 59.12.

7）岡村 甫・前川宏一：研究展望一鉄筋コンクリートにお ける非線形有限要素解析, 土木学会論文集, No. $360 / \mathrm{V}$ -3 , pp. $1 \sim 10$, 昭 60.8 .

8) Ohsaki, Y., Ibe, Y. and Aoyagi, Y. : Drafted Japanese Design Criteria for Concrete Containment, SMiRT-6, $\mathrm{J} 1 / 2,1981$.

9) Nielsen, M.P. : Limit Analysis and Concrete Plasticity, Prentice-Hall Series in Civil Engineering Mechanics, 1984.

10) Chen, W.F. : Plasticity in Reinforced Concrete, McGraw-Hill, 1982.

11) Marti, P. : Plastic Analysis of Reinforced Concrete Shear Walls, Introductory Report of IABSE Colloquium, Copenhagen, Plasticity in Reinforced Concrete, pp. $51 \sim 69,1979$.

12）小野 薫・田中 尚：鉄筋コンクリート壁体の Limit Design, 日本建築学会論文集, 第 49 号, pp. $42 \sim 48$, 昭 29. 9.

13）南 宏一：せん断を受ける鉄筋コンクリート部材の極限 解析について, RC 構造のせん断問題に対する解析的研 究に関するコロキウム論文集, 日本コンクリート工学協 会, pp. $1 \sim 16$, 昭 57.6 .

14）檜貝 勇：最近の塑性理論およびトラス理論について,
$\mathrm{RC}$ 構造のせん断問題に対する解析的研究に関するコロ キウム論文集，日本コンクリート工学協会，pp. 17～24, 昭 57.6.

15）白井仲明・白石一郎・村上利憲： RC 耐震壁の終局強度 に関する既往のマクロモデルについて， RC 耐震壁のマ クロモデルと FEM ミクロモデルに関するパネルディス カッション論文集, 日本コンクリート工学協会, pp. 5〜 20 , 昭 63.1 .

16）南 宏一・渡辺史夫：RC 耐震部材のせん断設計式の開 発一日本建築学会 $\mathrm{RC}$ 耐震設計小委員会せん断 WG の考 え方一, RC 耐震壁のマイクロモデルと FEM ミクロモ デルに関するパネルディスカッション論文集, 日本コン クリート工学協会, pp. 21〜 40, 昭 63.1.

17) Nielsen, M.P. : Yield Conditions for Reinforced Concrete Shells in the Membrane State, Proc. IASS Symposium, Warsaw 1963, Amsterdam 1964, pp.1030 1040.

18) Nielsen, M. P. : On the Strength of Reinforced Concrete Discs, Acta Polytechnica Scandinavica, Civil Engineering and Building Construction Series No.70, Copenhagen, 1971.

19) Braestrup, M.W., Nielsen, M. P. and Bach, F. : Plastic Analysis of Shear in Concrete, Hauptvortrage, T 3-T 14, 1978.

20) Vecchio, F. and Collins, M. P. : The Response of Reinforced Concrete to In-Plane Shear and Normal Stresses, University of Toronto, Department of Civil Engineering, No. 82-03, March, 1982.

21）角 一行・長 稔・薬研地彰・川股重也：鉄筋コンク リート平板におけるコンクリートの力学的特性（その 2 : コンクリートストラットの応力ーひずみ関係), 日本建 築学会大会学術講演梗概集 (近畿), pp. $367 \sim 368$, 昭 62. 10 .

22）宮原長久・川上泰司・前川宏一：ひびわれを含む鉄筋コ ンクリート板要素の一軸圧縮応力下における非線形挙動, 土木学会論文集, 第 378 号 $/ \mathrm{V}-6$, pp. 249 258, 昭 62.2 .

23) Jensen, B. C. : Lines of Discontinuity for Displacements in the Theory of Plasticity of Plain and Reinforced Concrete, Magazine of Concrete Research, Vol.27, No. 92, pp. 143 150, Sep. 1975.

24）檜貝 勇：鉄筋コンクリートはりのせん断破壊における 塑性理論の検討, 第 36 回土木学会年次学術講演会概要集, V-150, pp. 298 299, 昭 56. 10 .

25) Exner, H. : On the Effectiveness Factor in Plastic Analysis of Concrete, IABSE Colloquium, pp. 35 42, 1980.

26）吉川弘道・田辺忠顕：塑性理論による面内せん断耐力式 と各種算定式との比較, 土木学会論文集第 $\mathrm{V}$ 部門(投稿中)

(1988.5.24・受付) 